\title{
Sexual behaviors among men who have sex with men: a quantitative cross sectional study in Kathmandu Valley, Nepal [Expression of concern]
}

\author{
Mishra SR, Khanal V. HIV/AIDS - Research and Palliative \\ Care. 2013:5 81-88. \\ Following the publication of this article, the Editor-in-Chief \\ and Publisher were alerted to concerns over terminology used, \\ errors in the reference list, and unacceptable levels of similar \\ text with a previously published paper: Deuba K, et al. Risk \\ of HIV infection among men having sex with men in Kath- \\ mandu Valley, Nepal. Asia-Pacific Journal of Public Health. \\ DOI: http://dx.doi.org/10.1177/1010539512441491.
}

The authors were contacted in relation to these concerns and provided timely, adequate answers to all issues raised. The authors admit and apologize for two major mistakes: the missing reference of Deuba et al; and the errors in the reference list. All other concerns were adequately answered.

In light of these, the Editor-in-Chief and Publisher are issuing this Expression of Concern to make readers aware of these points.

\section{Publish your work in this journal}

HIV/AIDS - Research and Palliative Care is an international, peerreviewed open-access journal focusing on advances in research in HIV, its clinical progression and management options including antiviral treatment, palliative care and public healthcare policies to control viral spread. The journal welcomes original research, basic science, clinical \& epidemiological studies, reviews \& evaluations, expert opinion \& commentary, case reports \& extended reports. The manuscript management system is completely online and includes a very quick and fair peer-review system. Visit http://www.dovepress.com/ testimonials.php to read real quotes from published authors. 